technical detail that even the specialist has to pause for thought at the end of each sentence. There are some good line drawings in the book, but they are too few and, infuriatingly, are not numbered or alluded to in the text.

Printers' errors are few, but factual errors are easier spotted: e.g. medieval church towers were not primarily defensive (p. 128), and William of Sens was employed as architect at Canterbury, not Westminster (p. 61). There are some unfortunate repetitions, not only of examples cited, but also of the actual wording used (compare the descriptions of arch-deformation

\section{Editorial notices}

ANTIQUITY was founded in 1927 by Dr O.G.S. Crawford, with the assistance of Mr Roland Austin. Since January 1961 it has been owned by the Antiquity Trust (Trustees: Professor R.J.C. Atkinson, Warwick Bray, Professor J.M. Coles, Professor B.W. Cunliffe, Ruth Daniel, Jacquetta Hawkes, Professor Stuart Piggott, Professor A.C. Renfrew, and Sir David Wilson). It is published by Antiquity Publications Limited (owned and controlled by the Antiquity Trust; Directors: John Alexander, Christopher Chippindale, Joan Oates, Professor Anthony Snodgrass).

ANTIQUITY is published every four months, on 1 March, 1 July and 1 November. The annual subscription is $£ 17.50$ in Britain and the rest of the world, $\$ 35$ in the USA. This is payable annually in advance to AnTiQUiTy, c/o The Black Bear Press, King's Hedges Road, Cambridge $\mathrm{CB} 42 \mathrm{PQ}$. Giro number 2410257. Single copies of this number are $€ 7.50 / \$ 12.50$.

Copies of back-numbers, where available, are $£ 5 / \$ 10$. Index volumes are available: to vols. I-XXV (1927-51), clothbound $£ 5 / \$ 10$; to vols. XXVI-L (1952-76) clothbound $£ 10 / \$ 20$, or paperbound £8/\$16. Send orders, with payment, to ANTIQUTTY, c/o The Black Bear Press, King's Hedges Road, Cambridge CB4 2PQ.

Binding of ANTIQUTTY is best arranged by writing direct to: J.S. Wilson and Son, 17 Ronald Rolph Court, Wadloes Road, Cambridge CB5 8PX. processes on pp. 71 and 100). At times Fitchen's writing is overwhelmingly verbose: there are too many adjectival phrases; countless sentences begin, 'To be sure, ...'; and almost every piece of builder's equipment, from a ladder to a camel, is described as 'indispensable'.

Despite these shortcomings - essentially resulting from the conflation of a general work with a technical treatise - this book should be read by all who are concerned with the archaeology of buildings.

WARWICK RODWELL

In citing radiocarbon dates, ANTIQUITY follows the convention of lower-case letters for uncalibrated measurements, as b.p. (sometimes also a.d. and b.c.), and of small capitals for measurements calibrated into 'real' dates in calendar years, as $\mathrm{BP}, \mathrm{AD}, \mathrm{BC}$.

Editor: Christopher Chippindale.

Production editor: Anne Chippindale.

Advisory editors: Warwick Bray (U of London), Brian Fagan (U of California, Santa Barbara), Norman Hammond (Rutgers $U$ ), Anthony Harding ( $U$ of Durham), Charles Higham (U of Otago), Harry Lourandos (U of Queensland), Vincent Megaw (U of South Australia \& U of Leicester), Jeremy Sabloff (U of Pittsburgh), Ezra Zubrow (SUNY, Buffalo, NY).

Please send articles offered for publication to the editor at Girton College, Cambridge CB3 0JG, England; a preliminary letter summarizing a proposed article is often helpful. Send two clear photocopies of the text and of illustrations or roughs. Preferred style is as you find it in this number.

Please send books for review to the editor at the same address.

Rate cards and other details of advertising and inserts are available from the Production editor.

ISSN $0003598 x$

(C) Antiquity Publications 1987

Set in Linotron 202 Melior by Alan Sutton Publishing Ltd/Antiquity Publications L.td. Printed and bound in Great Britain by The Black Bear Press Ltd. 